\title{
UPAYA PENCEGAHAN PENYEBARAN COVID-19 DENGAN PENYEMPROTAN DISINFEKTAN DAN PEMBAGIAN MASKER
}

\author{
Unung Lesmanah*, Harada Purwanto, Agus Tri, Bayu Irawan, Muhammad Aditya \\ Yanuar, Moch. Habib Zain, Ilham Dwi Prastio, M. Nur Khalim, Fitra Ainur Rosyid, \\ Moh. Hidayatur Rohman, Diki Candra Prastiyo, Muhammad Rafli, Muhammad Al- \\ Rizki, Yawan Fauzy Dharmawan \\ Fakultas Teknik, Universitas Islam Malang \\ *korespondensi email: ununglemanah@unisma.ac.id
}

\begin{abstract}
ABSTRAK
Banyaknya penambahan kasus Covid-19 disebabkan beberapa faktor salah satunya yaitu muncul beragam varian atau mutasi dari Covid-19 termasuk varian Alpha, Beta, Gamma serta yang terbaru varian Delta yang sempat menjadi faktor lonjakan kasus di Indonesia pada Juli lalu. Permasalahan tersebut masih terus berjalan di Indonesia sampai detik ini. Permasalahan yang sering terjadi di era pandemi yaitu kurangnya kepedulian masyarakat dalam menjaga kebersihan serta kesehatan diri sendiri, selain itu kurang patuhnya masyarakat dalam menaati protokol kesehatan yang sudah dianjurkan oleh pemerintah. Berdasarkan permasalahan tersebut, KSM-Tematik Kelompok 105 membuat program yang memiliki tujuan sejalan dengan pemerintah yaitu menanggulangi dan memutus rantai penyebaran Virus Covid-19. Program kerja yang dibuat yaitu pembagian masker dan penyemprotan disinfektan. Pembagian masker bertujuan untuk mengingatkan warga di desa tersebut agar selalu ingat dan patuh terhadap protokol kesehatan. Sedangkan, penyemprotan disinfektan dilakukan dengan tujuan untuk memusnahkan penyebaran Virus Covid-19 di desa tersebut. Kegiatan tersebut memberikan efek positif, baik dari sisi pemerintah maupun dari sisi masyrakat. Salah satu efek positif yang terjadi yaitu kegiatan tersebut memberikan kesadaran masyarakat dalam mentaati protokol kesehatan secara sukarela dan konsisten.
\end{abstract}

Kata Kunci: pembagian masker; penyemprotan disinfektan; covid-19

\section{PENDAHULUAN}

Kasus Virus Covid-19 di Indonesia semakin meninggi tercatat per tanggal 13 September 2021 kasus positif bertambah sebanyak 2.577 orang, sehingga total kasus Covid19 di Indonesia menjadi 4.170.088 sejak pertama terkonfirmasi pada Maret 2020 lalu (Alfatih \& Aulia, 2021; Safi et al., 2021; Wahidah et al., 2020). Kasus Covid-19 hingga kini juga banyak memakan korban jiwa, tercatat total kasus meninggal dunia akibat Covid-19 per tanggal 13 September 2021 yaitu sebanyak 139.165 orang (Maleha et al., 2021; Mujiburrahman et al., 2021). Banyaknya penambahan kasus Covid-19 disebabkan beberapa faktor salah satunya yaitu muncul beragam varian atau mutasi dari Covid-19 termasuk varian Alpha, Beta, Gamma serta yang terbaru varian Delta yang sempat menjadi faktor lonjakan kasus di Indonesia pada Juli lalu (Amindoni, 2021; Sofa, 2021). Permasalahan tersebut masih terus berjalan di Indonesia sampai detik ini. Pemerintah juga mengupayakan 
beberapa kebijakan agar dapat mengendalikan serta memusnahkan Virus Covid-19 salah satunya yaitu kebijakan pada bidang pendidikan.

Kebijakan yang diberlakukan dalam bidang pendidikan yaitu Kementerian Pendidikan dan Kebudayaan (Kemendikbud) menegaskan bahwa izin kegiatan pembelajaran tatap muka di perguruan tinggi dan politekenik/akademi komunitas pada semester genap Tahun Akademik 2020/2021 dapat dilakukan secara campuran (hybrid learning), dalam jaringan, dan tatap muka, dengan protokol kesehatan yang ketat. Adanya kebijakan tersebut berdampak pada setiap program perkuliahan yang terjadi di era pandemi. Program kuliah dimodifikasi oleh pihak kampus sedemikian rupa sehingga dapat terlaksana secara efektif dan efisien. Salah satu program kuliah yang dimodifikasi di era Pandemi yaitu Kandidat Sarjana Mengabdi (KSM-Tematik). Dimana program KSM-Tematik merupakan pengganti program Kuliah Kerja Nyata (KKN) dapat menetap pada desa tertentu tanpa menyebar sesuai domisili anggota. Sedangkan, KSM-Tematik dilakukan secara menyebar dengan berbasis domisili dan bidang Keilmuan. KSM-Tematik dibagi menjadi beberapa kelompok, salah satunya yaitu kelompok105 KSM-Tematik.

KSM-Tematik Kelompok 105 tersebar di berbagai desa di Kabupaten Malang salah satunya Desa Wonokerso Kecamatan Pakisaji. Dari beberapa program kerja yang dilaksanakan, KSM-Tematik Kelompok 105 bersama Satgas Covid-19 membuat program yang memiliki tujuan sejalan dengan pemerintah yaitu menanggulangi dan memutus rantai penyebaran Virus Covid-19. Program kerja yang dibuat yaitu pembagian masker dan penyemprotan disinfektan. Pembagian masker bertujuan untuk mengingatkan warga di desa tersebut agar selalu ingat dan patuh terhadap protokol kesehatan. Sedangkan penyemprotan disinfektan dilakukan dengan tujuan untuk memusnahkan penyebaran Virus Covid-19 di desa tersebut. Kegiatan tersebut dilakukan agar masyarakat mengetahui pentingnya mematuhi protokol kesehatan pada kondisi saat ini. Selain itu, masyarakat dapat meningkatkan kepeduliaan diri sendiri dan orang lain seperti orang yang ditemui atau saat berinteraksi. Pengabdian tersebut dilakukan karena KSM-Tematik Kelompok 105 menyadari dan mengganggap serius akan Virus Covid-19 pada saat ini. Selain itu, KSMTematik Kelompok 105 memiliki maksud dan tujuan agar elemen masyarakat yang belum memperoleh fasilitas berupa media protokol kesehatan dapat terbantu sehingga masyarakat dalam melakukan kegiatan atau aktifitas sehari-hari tidak merasa khawatir akan Virus Covid-19.

\section{METODE}

Pembagian Masker dan penyemperotan disinfektan dilakukan di Desa Wonokerso, Kecamatan Pakisaji, Kabupaten Malang. Kegiatan tersebut dilaksanakan pada Hari Senin, Tanggal 09 Agustus 2021. Kegiatan penyemprotan disinfektan dilakukan pada lingkungan sekitar yaitu seluruh wilayah di Desa Wonokerso.

Akomodasi yang digunakan yaitu berupa mobil bak terbuka, dengan membawa peralatan semprot listrik otomatis, serta genset sebagai sumber energi listriknya. Bahan yang digunakan yaitu cairan disinfektan sebanyak 5 liter yang dicampur dengan air bersih yang ada di dalam tandon yaitu sebanyak 50 liter. Sedangkan, pembagian masker dilakukan dengan cara mengemas 2 biji masker ke dalam plastik. Pembelian masker sebanyak 10 kotak masker,1 kotak masker berisi sebanyak 50 biji masker. Jadi, masker yang dapat dibagikan sebanyak 250 bungkus masker kepada masyarakat Desa Wonokerso. Pelaksanaan kegiatan dilakukan pukul 08.00. Kegiatan penyemprotan dilakukan dengan cara menyemprot disinfektan ke depan rumah warga, sedangkan pembagian masker diberikan pada masyarakat yang belum menggunakan masker saat terlihat waktu dilakukan penyemprotan. 


\section{HASIL DAN PEMBAHASAN}

Permasalahan yang sering terjadi di era pandemi yaitu kurangnya kepedulian masyarakat dalam menjaga kebersihan serta kesehatan diri sendiri, selain itu kurang patuhnya masyarakat dalam menaati protokol kesehatan yang sudah dianjurkan oleh pemerintah. Hal ini dapat dinyatakan karena melihat beberapa bukti visual, seperti masyarakat mengadakan suatu hajatan atau acara besar sehingga menimbulkan kerumunan tanpa adanya jaga jarak, dan masyarakat masih banyak yang belum menggunakan masker, ada pula penggunaan masker tidak digunakan secara tepat. Hal ini menunjukkan bahwa tingkat kesadaran masyarakat mengalami penurunan dalam hal menjaga kebersihan dan kesehatan yang tepat di era pandemi.

Berdasarkan permasalahan tersebut, KSM-Tematik Kelompok 105 mengadakan program kerja yaitu melakukan penyemprotan disinfektan serta pembagian masker kepada masyarakat yang belum memakai masker di Desa Wonokerso, Kecamatan Pakisaji, Kabupaten Malang. Pada dasarnya kegiatan tersebut dilakukan karena secara umum memiliki tujuan yang sama yaitu untuk membantu pemerintah dalam hal menanggulangi penyebaran virus Covid-19. Namun, kegiatan tersebut memiliki tujuan utama untuk masyarakat desa, yaitu KSM-Tematik Kelompok 105 berharap agar masyarakat setelah program tersebut dilakukan, tidak mengendorkan untuk tetap menjaga lingkungan agar tetap bersih dan steril, dan masyarakat diharapkan konsisten untuk tetap menjaga protokol kesehatan, sehingga hal ini dapat mewujudkan masyarakat yang tangguh dan sehat. Selain itu, KSM-Tematik Kelompok 105 dapat dijadikan motivasi bagi masyarakat sekitar bahwa merawat dan menjaga kesehatan dan kebersihan sangat penting di era Pandemi saat ini.

Pelaksanaan kegiatan penyemprotan disinfektan serta pembagian masker kepada masyarakat di Desa Wonokerso, Kecamatan Pakisaji, Kabupaten Malang dapat berjalan dengan lancar. Kegiatan tersebut berjalan dengan sukses berkat adanya kerjasama antara KSM-Tematik Kelompok 105 dengan Satgas Covid-19 Desa Wonokerso. Kegiatan tersebut dapat sukses karena beberapa faktor, sebagai berikut: (1) Kerjasama setiap anggota sangat konsisten sehingga menciptakan koordinasi kelompok secara baik dan cepat; (2) Peralatan dan bahan sudah disiapkan secara jauh-jauh hari; (3) Dukungan finansial dari setiap anggota dalam memenuhi semua kebutuhan yang dibutuhkan untuk kegiatan penyemprotan disinfektan serta pembagian masker; (4) Mudahnya perijinan dari pihak desa; (5) Ramahnya semuanya warga desa menyambut kegiatan yang dilakukan oleh KSM-Tematik Kelompok 105 dengan Satgas Covid-19 Desa Wonokerso.

Selain itu, KSM-Tematik Kelompok 105 dengan Satgas Covid-19 Desa Wonokerso juga mendapatkan beberapa kendala yang diperoleh saat kegiatan, antara lain: (1) Alat semprot yang digunakan terkadang macet dan berhenti beroperasi; (2) Genset membutuhkan banyak bahan bakar; (3) Jalan yang sempit dan rusak, sedikit menghambat perjalanan saat kegiataan dilakukan; (4) Saat kegiatan penyemprotan disinfektan, banyak warga tidak menjauh dari arah semprotan sehingga penyemprotan dilakukan kurang maksimal; (5) Beberapa warga menolak diberikan masker gratis, dengan alasan masih memiliki banyak masker di rumahnya.

Dari kendala yang terjadi, tidak mengurangi giat dari KSM-Tematik Kelompok 105 dan Satgas Covid-19 Desa Wonokerso. Dari giat tersebut, KSM-Tematik Kelompok 105 melakukan monitoring terhadap masyarakat. Satu per satu tujuan mengenai kegiatan penyemprotan disinfektan dan pembagian masker dari KSM-Tematik Kelompok 105 dapat tercapai, dan juga masyarakat lebih mematuhi protokol kesehatan yang tepat dilakukan saat era pandemi. Kegiatan tersebut dapat menyadarkan masyarakat akan pentingnya pola hidup bersih dan sehat, serta masyarakat saat ini meningkat kepedulian mengenai kebersihan lingkungan sekitar agar lingkungan sekitar dapat terjaga dan memberikan dampak positif 
terhadap warga di era pandemi saat ini. Berikut gambar visualisasi saat kegiatan penyemprotan dan pemabagian masker.

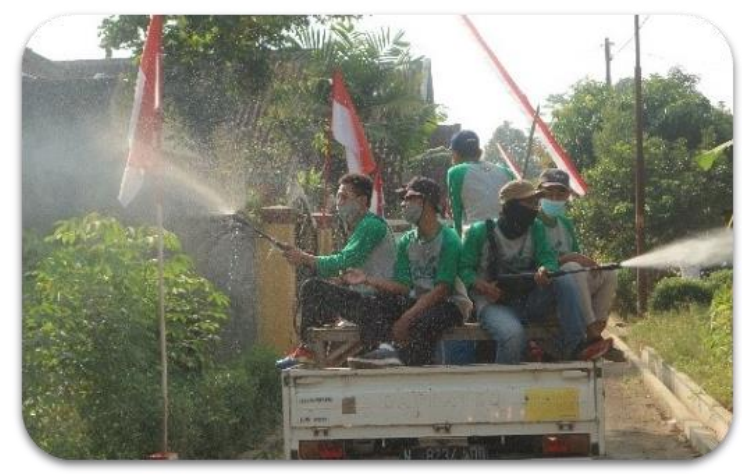

Gambar 1. Penyemprotan Disinfektan

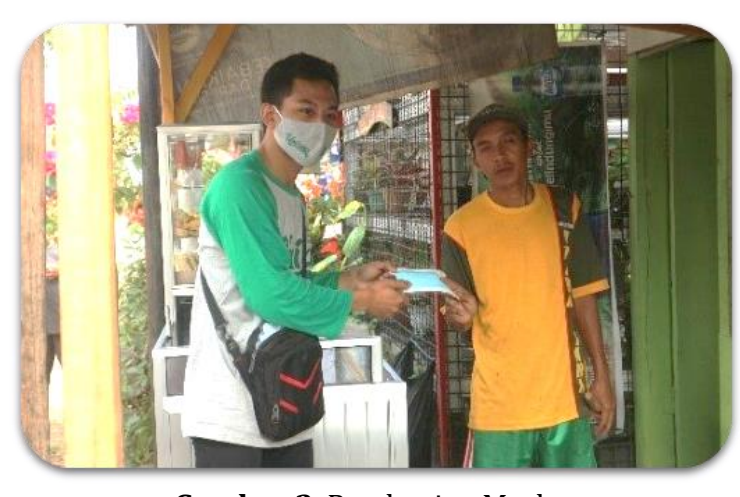

Gambar 2. Pembagian Masker

\section{KESIMPULAN}

Era pandemi terjadi masyarakat sulit untuk menjaga kondisi tubuh dari virus Covid19. Paparan virus Covid-19 juga mengalami peningkatan yang signifikan saat akhir-akhir ini. Selain itu, mutasi yang terjadi pada virus Covid-19 menyebabkan beberapa banyak varian virus yang dihasilkan. Hal ini semakin memperburuk keadaan yang tejadi di Indonesia. Pemerintah dan beberapa pihak sudah berusaha membuat kebijakan terbaru, salah satu diantaranya yaitu Kandidat Sarjana Mengabdi Tematik (KSM-Tematik).

Program ini dimaksudkan agar mahasiswa berjuang bersama dalam menanggulangi penyebaran virus Covid-19. KSM-Tematik Kelompok 105 mengadakan program kerja yaitu penyemprotan disinfektan dan pembagian masker. Kegiatan tersebut sejalan dengan apa yang diperintahkan oleh pemerintah dan juga secara umum memiliki tujuan yaitu memutus rantai penyebaran virus Covid-19. Kegiatan tersebut memberikan efek positif, baik dari sisi pemerintah maupun dari sisi masyrakat. Salah satu efek positif yang terjadi yaitu kegiatan tersebut memberikan kesadaran masyarakat dalam menaati protokol kesehatan secara sukarela dan konsisten.

\section{DAFTAR RUJUKAN}

Al-fatih, S., \& Aulia, F. I. (2021). Tanggung Jawab Negara dalam Kasus Covid-19 sebagai Perwujudan Perlindungan HAM. Jurnal HAM, 12(3), 349-366. https://doi.org/10.30641/ham.2021.12.349-366

Amindoni, A. (2021). Lonjakan Covid-19 di Indonesia: Varian Delta dan varian lokal mendominasi penularan, epidemiolog kritik respons antisipasi pemerintah Indonesia yang "tenang-tenang saja." BBC News Indonesia. 
https://www.bbc.com/indonesia/indonesia-57514155

Maleha, N. Y., Saluza, I., \& Setiawan, B. (2021). Dampak Covid-19 Terhadap Pendapatan Pedagang Kecil Di Desa Sugih Waras Kec. Jurnal Ilmiah Ekonomi Islam, 7(03), 14411448.

aas.ac.id/index.php/jiedoi:http://dx.doi.org/10.29040/jiei.v7i3.3476

Mujiburrahman, Riyadi, M. E., \& Ningsih, M. U. (2021). Pengetahuan Berhubungan dengan Peningkatan Perilaku Pencegahan COVID-19 di Masyarakat. Jurnal Keperawatan Terpadu, $2(2)$, 130-140. http://www.elsevier.com/locate/scp\%0Ahttp://arxiv.org/abs/1011.1669\%0Ahttp: //dx.doi.org/10.1088/1751-8113/44/8/085201

Safi, I., Candra, A. I., Widodo, S. R., Santoso, A., Heryanto, B., Winarti, E., \& Rahmadi, A. N. (2021). Pembuatan masker dan bilik disinfektan sebagai upaya membantu masyarakat terdampak covid-19. Jurnal Inovasi Hasil Pengabdian Masyarakat (JIPEMAS), 4(1), 36-45. https://doi.org/10.33474/jipemas.v4i1.7524

Sofa, A. (2021). Covid-19 Varian Delta dan Hal-hal yang Harus Kamu Perhatikan. https://smartcity.jakarta.go.id/blog/758/covid-19-varian-delta-dan-hal-hal-yangharus-kamu-perhatikan

Wahidah, I., Athallah, R., Hartono, N. F. S., Rafqie, M. C. A., \& Septiadi, M. A. (2020). Pandemik COVID-19: Analisis Perencanaan Pemerintah dan Masyarakat dalam Berbagai Upaya Pencegahan. Jurnal Manajemen Dan Organisasi (JMO), 11(3), 179-188. https://doi.org/10.29244/jmo.v11i3.31695 